\title{
MOSTRA DE CINEMA DE TIRADENTES: A ARQUITETURA EFÊMERA COMO PROTOGONISTA DA IDENTIDADE CONTEMPORÂNEA
}

\author{
Mostra de Cinema de Tiradentes: Temporary architecture as the lead role in the contemporary identity \\ Mostra de Cinema de Tiradentes: La arquitectura efímera como protagonista de la identidad contemporânea \\ Clarissa de Oliveira Neves \\ Centro universitário Metodista Izabela Hendrix, Belo \\ Horizonte, $M G$, Brasil \\ DOI: https://doi.org/10.18472/cvt.20n1.2020.1703 \\ Redalyc: http://www.redalyc.org/articulo.oa? \\ clarissa.arq@gmail.com \\ id $=115462634007$
}

Maria Luiza Almeida Cunha de Castro

Universidade Federal de Minas Gerais (UFMG), Belo

Horizonte, $M G$, Brasil

luizadecastro2000@gmail.com

Recepción: 09 Marzo 2019

Aprobación: 25 Mayo 2020

\section{Resumo:}

Este artigo apresenta a Mostra de Cinema de Tiradentes em suas relações com a cidade, com seu patrimônio construído e com a configuração de sua identidade, destacando elementos da arquitetura efêmera que lhe dá suporte e a sua articulação com o contexto. $\mathrm{O}$ artigo discute as relações entre patrimônio e as novas dinâmicas contemporâneas na configuração de uma identidade local e descreve a evolução das instalações da Mostra em seu diálogo com o contexto, partindo de uma abordagem qualitativa, descritiva e coleta de dados primários.

Palavras-chaVe: Tiradentes, Patrimônio, Mostra de Cinema, Identidade.

\section{Abstract:}

This paper presents the Tiradentes Film Festival in its relations with the city, with its built heritage and with the configuration of its identity, highlighting elements of the ephemeral architecture that supports it and its articulation with the context. The paper discusses the relations between built heritage and new contemporary dynamics in the configuration of a local identity and describes the evolution of the event's facilities in their dialogue with the context, adopting a qualitative and descriptive approach, with primary data collection.

KEYwords: Tiradentes, Heritage, Film Festival, Identity.

\section{ReSUMEN:}

Este artículo presenta el Festival de Cine de Tiradentes en sus relaciones con la ciudad, con su patrimonio construido y con la configuración de su identidad, destacando elementos de arquitectura efímera que la sostienen y su articulación con el contexto. El artículo analiza las relaciones entre el patrimonio construido y la nueva dinámica contemporánea en la configuración de una identidad local y describe la evolución de las instalaciones de la mostra en su diálogo con el contexto, partiendo de un enfoque cualitativo, descriptivo y de recopilación de datos primarios.

Palabras llave: Tiradentes; Patrimonio; Festival de cine; Identidad

\section{INTRODUÇÃo}

O objetivo deste artigo é apresentar a Mostra de Cinema de Tiradentes em suas relações com a cidade e com a arquitetura efêmera que lhe dá suporte. $O$ evento é a expressão máxima das dinâmicas que prevalecem em Tiradentes atualmente e está em sintonia com o conceito contemporâneo de identidade, que busca uma articulação com a complexidade do mundo globalizado. Além da Mostra se materializar por meio de uma sequência de construções temporárias, que evoluem a cada ano, acompanhando as tendências e se adaptando a necessidades e demandas, a própria virtualidade do tema em exposição - o cinema - remete ao famoso 
questionamento de Benjamim (1996), sobre a validade da obra de arte na era da sua reprodutibilidade técnica. A efemeridade da exposição temporária se contrapõe à materialidade do patrimônio construído e esta interação reconfigura e atualiza o sentido da cultura, que é reconstruído a cada edição do evento, deixando ao mesmo tempo suas marcas na identidade local.

Realizada sempre na segunda quinzena de janeiro, e com duração de oito a nove dias, a Mostra é um evento de caráter cultural que pretende divulgar e ampliar o debate sobre a nova produção do cinema brasileiro, contribuindo para a formação, reflexão, exibição e difusão dos novos filmes, além de trazer impactos diretos para o turismo, economia e paisagem da cidade histórica de Tiradentes (MG).

A inserção local da Mostra ocorreu dentro de uma dinâmica de atualização da identidade local, a partir de um contexto globalizado. Antes da criação da Mostra, a cidade havia se articulado por meio da ação conjunta entre vários agentes públicos e privados para recuperação de seu patrimônio[1]. Esta configuração de um cenário tradicional, refletindo aspectos de uma brasilidade já identificada desde a década de 1920 por intelectuais modernistas, levou à utilização da cidade para a locação de filmes e novelas, fato que criou uma articulação com o tema do cinema e acabou por levar à proposta da Mostra.

A arquitetura temporária das instalações de suporte ao evento tem evoluído de acordo com o diálogo que ele estabelece com o entorno, contribuindo para a criação de uma identidade que consegue articular o passado histórico e a contemporaneidade. Desta forma, a Mostra em Tiradentes, que completou vinte e três edições em 2020 , abriu caminho para diversos outros festivais e eventos, consolidando a cidade como um destino indutor de turismo mineiro e nacional (Brasil, 2018, p.55).[2]

A pesquisa realizada partiu de uma abordagem qualitativa, descritiva, com coleta de dados primários, que ocorreu por meio de pesquisa documental e entrevistas, incluindo ainda a observação participante. A aplicação de entrevistas não estruturadas foi realizada no período de agosto a novembro de 2018. O material disponibilizado para consulta e análise, pela organização do evento, permitiu a reconstituição de fatos, impactos e impressões e incluiu fotografias, vídeos, relatórios, memoriais, documentos, projetos aprovados junto a instâncias normativas e regulatórias, além de reportagens de jornais.

\section{IDENTIDADE EM RECONSTRUÇÃO: NOVA INSERÇÃO DO PATRIMÔNIO NA DINÂMICA URBANA GLOBALIZADA}

A ideia da preservação do patrimônio em cidades ditas "históricas" coloca em confronto diversos reflexos da realidade, que podem ser conflitantes. Inicialmente, trata-se de reafirmar um passado que não mais existe mas que pode estar enraizado na tradição e na cultura local - e de viabilizar a sua apropriação, de maneira que ele possa integrar a identidade local. Porém, as tentativas neste sentido que não incorporarem o espírito da época, estarão condenadas a se tornar um eco vazio do passado, desprovido de sentido (Dorfles, 1991, p. 22).

Por outro lado, a gestão deste processo está, em geral, diretamente ligada às estratégias do mercado globalizado, em um processo de mercantilização da cultura (Costa \& Castro, 2008, p. 27). Existem muitos estudos que tratam dos efeitos da globalização sobre as identidades locais e da dialética global/local (Bauman, 1999; Harvey, 1992; Santos, 2000). A compressão espaço/tempo (Harvey, 1992) provocada pela globalização impõe uma homogeneização do espaço, e associada ao avanço do capitalismo tem consequências perversas, que dividem setores da sociedade (Canclini, 1997), criam classes de excluídos, promovem práticas mercantis predatórias.

Para combater estes efeitos, não basta verbalizar e organizar uma resistência ao avanço e às mudanças. Sobre as alternativas que a globalização nos apresenta, Bauman (2005, p. 93) reflete:

Lançados num vasto mar aberto, sem cartas de navegação e com todas as bóias de sinalização submersas e mal visíveis, só nos restam duas opções: ou nos alegramos com as empolgantes perspectivas de novas descobertas ou podemos tremer de medo de morrer afogados. 
Desta forma, é importante reconhecer que dinheiro e mercadorias são, em última instância, "portadores primários de códigos culturais", carregando "valores e significados sociais", constatação que nos leva à conclusão de que as formas culturais têm firmes raízes no processo diário da circulação do capital (Harvey, 1992, p. 269). Por outro lado, a estratégia mais eficaz para lidar com processos que não conseguimos reverter é identificar seus mecanismos e articulações, ou seja, as "regras do jogo" - e procurar alternativas disponíveis dentro do contexto existente, que possam contribuir para sua evolução rumo a um futuro desejado.

O passado foi por longo tempo considerado uma das dimensões mais importantes das identidades, origem de uma memória compartilhada. Ao mesmo tempo, ele traz uma sensação de segurança face à desarticulação e fragmentação do presente e provê raízes que permitem às pessoas se situar, transmitindo uma sensação - ou uma ilusão - de segurança (Abreu, 2017, p. 21). Entretanto, seu papel, enquanto foco da construção de uma identidade local, precisa ser reavaliado.

A heterogeneidade das populações urbanas, formadas por indivíduos de origem, classes e histórias diferentes, resultado de intensos movimentos migratórios e reformulações sociais, demonstra que na maioria dos casos não há atualmente um passado comum a ser compartilhado, e as referências a ele não são mais suficientes como elemento catalizador de uma identidade, dentro de um contexto globalizado (Bauman, 1999; Geertz, 2001; Hall, 2006). As referências ao passado também não conseguem assegurar a vitalidade em um mundo fragmentado, onde tudo é efêmero e mutável (Geertz, 2001, p.219). Esta ausência de raízes gera uma instabilidade das identidades, que é consequência lógica da "matéria prima" que as compõe: a realidade "líquida”, cuja estrutura não se sustenta, e requer flexibilidade e velocidade de reajuste (Bauman, 2001). As consequências deste processo são controversas: são, portanto, "bênçãos mistas - tanto tentadoras e desejadas quanto repulsivas e temidas, e despertam os sentimentos mais contraditórios" (Bauman, 2001, p.107).

Em contraposição a uma identidade assentada sobre o passado, a perspectiva atual das ciências sociais propõe, portanto, a configuração de uma identidade de destino, direcionada para o futuro, baseada nas aspirações dos grupos, em seus objetivos comuns (Bauman, 2005), construída a partir dos elementos que os distinguem (Geertz, 2001, p.219). Esta nova ideia de identidade é provisória e parcial, dentro de um ambiente de modernidade "líquida" (Baumann, 2001), e ela está sempre em vias de reconstrução porque os hábitos são efêmeros, postos de lado na primeira oportunidade (Bauman, 2001; Hall, 2006).

Essa dinâmica é evidenciada no ambiente urbano, que é palco privilegiado para a complexidade, desarticulação, contradições, lutas e confrontos que conformam a sociedade e configuram as identidades. Canclini (1997) destaca as relações entre as forças marcantes que estão presentes e sua expressão material: nas cidades, os monumentos expressam o poder das elites, responsáveis pela definição daquilo que vale a pena ser preservado; os cartazes comerciais mostram o poder econômico na atualidade; os grafites demonstram uma crítica popular latente; além disso, existem ainda outras manifestações políticas e econômicas. $\mathrm{O}$ autor descarta, desta forma, a ideia de que existiria uma chave para os sistemas culturais baseada nas relações da população com certo tipo de território e de história.

Desta forma, as identidades urbanas se configuram não apenas a partir de componentes históricos, folclóricos, artísticos, mas envolvem hoje, principalmente, componentes comunicacionais e políticos, essenciais para sua articulação - além dos componentes sociais, expressão das relações entre os atores locais, o espaço em suas múltiplas dimensões e o mundo contemporâneo (Castro \& Ximenes, 2006)

As dinâmicas urbanas contemporâneas fazem, portanto, com que todos os interesses se cruzem, facilitando "que a memória interaja com a mudança, que os heróis nacionais se revitalizem graças à propaganda ou ao trânsito: continuam lutando com os movimentos sociais que sobrevivem a eles (Canclini, 1997, p. 301).

Assim, é imprescindível dar livre curso ao fluxo dessas dinâmicas, permitir o desenvolvimento dos processos econômicos contemporâneos e viabilizar as vivências emergentes, com todas as necessidades de transformação material inerentes, como por exemplo as relativas à mobilidade (diferentes modais de transporte e a infraestrutura necessária) ou ao conforto (eletricidade, redes tecnológicas de comunicação, 
entre outras). Ao mesmo tempo, deve-se articular novas formas de apropriação do patrimônio, para que ele não se torne um "referente de identificação" "embalsamado" pelo folclore em um estágio 'tradicional' de seu desenvolvimento.[3]

Dessa forma, as políticas e iniciativas locais nas cidades históricas devem ser direcionadas não somente para a preservação do patrimônio, mas também para o resgate de uma perspectiva mais centralizada nas múltiplas articulações que o espaço viabiliza, que podem incluir o passado mas que, dado o contexto, vão naturalmente incluir outros processos contemporâneos, incluindo aqueles ligados ao capitalismo.

Em Tiradentes, o confronto entre a s diferentes perspectivas da realidade local resulta em processos de hibridização que são mais marcantes do que em outras cidades históricas da região, como São João del Rei, ou Ouro Preto: a história da cidade tem sido efetivamente ofuscada, suas referências têm se diluído e dado lugar a um passado inventado, a partir do qual são gerados cenários, que buscam sentido na "brasilidade" aquilo que nos distingue - na sociabilidade e convivialidade que a experiência local viabiliza.

Esses cenários são pano de fundo para o turismo e se afirmam por meio das inúmeras filmagens - minisséries, filmes de curta e longa metragem - que têm ocorrido na cidade e não procuram se alinhar com a memória ou com a tradição local[4], e também dos eventos efêmeros, que se tornaram a marca registrada da cidade.

Atribui-se esta negligência do passado - um processo de "banalização pela cenarização" - à globalização, às novas técnicas, "à instantaneidade da informação", à atuação do capital transnacional. Recrimina-se a falta de "real preocupação de resgatar o sentido histórico-cultural que um dia nós mesmos atribuímos a esses bens" (Costa \& Castro, 2008, p. 48).

E é de fato notório que o centro histórico de Tiradentes passou por um processo de produção simbólica que converteu a cidade em mercadoria (Neves \& Carneiro, 2014, p.72). Em contraposição ao passado, a contemporaneidade e o mercado aí se impuseram - a primeira, sob a forma de outras manifestações da cultura, das relações estabelecidas com o entorno, e de novas formas de sociabilidade; o segundo, sob diversas formas de reprodução econômica.

O ambiente urbano com suas contradições configura, assim, a identidade cultural que emerge, promove o turismo e reconcilia - embora pontual e provisoriamente - forças que muitas vezes parecem irreconciliáveis, fazendo com que práticas sociais adquiram sentido na medida em que se institucionalizam, que são reconhecidas, que ampliam o campo da criatividade.

A flexibilidade da configuração cultural local, a transitoriedade das manifestações culturais e as constantes mudanças observadas estão em sintonia com uma dinâmica de tempo acelerado, que tem transformado as variadas formas de expressão artística e cultural, muitas vezes privilegiando processos em oposição a produtos, e eventos em oposição a objetos (Bauman, 2005).

Neste contexto, os eventos que ocorrem em Tiradentes são exemplares: incorporando a volatilidade característica da identidade local fugidia, eles se reconstroem permanentemente e são a essência mesma das características que resultam da interação das forças urbanas em confronto. Eles são hoje a principal "mola" do turismo na cidade e estão diretamente articulados com uma arquitetura efêmera.

A arquitetura efêmera responde à demanda de reconfiguração e transitoriedade. Pelo fato de ser temporário e produzir menores impactos, este tipo de construção pode ser montado em locais em que outras modalidades seriam inviáveis - como, por exemplo, em terrenos inundáveis, sujeitos a stress climático; ou em áreas históricas, lado a lado com o patrimônio tombado. A sua instalação altera a dinâmica local, abrindo novas perspectivas para vivenciar o espaço. Assim, a arquitetura efêmera materializa a velocidade da experiência contemporânea e dialoga com o contexto urbano de uma forma que, embora provisória, imprime uma "presença permanente na memória daqueles que participam" do processo, transformando de maneira definitiva a percepção do espaço (Kronenburg, 2010, p. 308).

A Mostra de Cinema, evento mais representativo do ponto de vista da arquitetura efêmera em Tiradentes, coloca em pauta a "brasilidade" por força de sua temática - o cinema brasileiro - e representa, ao mesmo tempo, as características de configuração de uma identidade nos tempos atuais. Como nos lembra Benjamim (1996), 
ao discutir as representações do mundo e o valor de culto - de contemplação - quando ele se deixa suplantar pelo valor de exposição:

O cinema é a forma de arte correspondente aos perigos existenciais mais intensos com os quais se confronta o homem contemporâneo. Ele corresponde a metamorfoses profundas do aparelho perceptivo, como as que experimenta o passante, numa escala individual, quando enfrenta o tráfico, e com as experimenta, numa escala histórica, todo aquele que combate a ordem social vigente (p. 192)

\section{Tiradentes: DA EXPLORAÇÃo DO OURO À EXPLORAÇÃo DO TURISMO}

Tiradentes está localizada na região central de Minas Gerais, fazendo parte da Serra da Mantiqueira, com relevo montanhoso e muitas nascentes de rios. As principais atividades econômicas atualmente são o turismo, a fabricação de produtos de minérios não metálicos, a metalurgia básica e as atividades agropecuárias.

A região, percorrida anteriormente por bandeirantes e habitada pelos índios Cataguás, começou a ser ocupada efetivamente em 1702, quando os paulistas encontraram ouro nas encostas da Serra de São José. Inicialmente denominado Arraial de Santo Antônio ou Arraial Velho, em 1718, foi desmembrado da Vila de São João Del Rei, recebendo o nome de Vila São José do Rio das Mortes. Em 1860, a vila foi elevada a cidade. (Plano de Inventário, TIRADENTES, 2005)

O nome Tiradentes, homenagem ao alferes Joaquim José da Silva Xavier, nascido na região do rio das Mortes, um dos principais protagonistas da Inconfidência Mineira, surgiu ao ser proclamada a República, em 1889, com a necessidade de criar heróis nacionais representando os novos ideais republicanos.

Durante todo o século XVIII, a região cresceu principalmente através da exploração do ouro e, com seu esgotamento no final deste século e no início do seguinte, houve um esvaziamento da cidade e as atividades econômicas principais passaram a ser a agricultura e a pecuária. Durante todo o século XIX, a cidade atravessou um período de estagnação, que perdurou até a segunda metade do séc. XX, fato que permitiu, por outro lado, que seu conjunto urbanístico-arquitetônico fosse pouco alterado (Pellegrini, 2000).

$\mathrm{Na}$ década de 1920, vários artistas e intelectuais modernistas, como Mário de Andrade, Tarsila do Amaral e Oswald Andrade, visitaram a cidade, despertando o interesse pela região e levando ao tombamento do conjunto arquitetônico e urbanístico pelo Serviço do Patrimônio Histórico e Artístico Nacional (SPHAN - atualmente IPHAN) em 1938.

O tombamento como sítio histórico levou em consideração o conjunto da cidade, e não bens isolados, evitando, desta forma, uma descaracterização e mantendo as características da cidade colonial preservadas dentro do conceito de identidade nacional da época.

A recuperação econômica local, porém, só começou realmente na década de 1980, com o despertar para o seu potencial turístico. Em um primeiro momento, a atração dos visitantes foi motivada pela tranquilidade, culinária regional, pela natureza e, principalmente, pelo ar bucólico do núcleo histórico. $\mathrm{N}$ um segundo momento houve a criação de uma agenda de eventos no município, com a valorização de festas tradicionais e a criação dos diversos festivais que hoje lá ocorrem e que deram origem ao turismo cultural. Atualmente o turismo, setor terciário, passou a ter uma importância significativa na vida da cidade, sendo responsável pela geração de novos empregos, ativando a economia local, "alterando o viver cotidiano da população local” (Plano de Inventário, TIRADENTES, 2005, p. 20).

\section{A Mostra de Cinema de Tiradentes}

De acordo com o jornalista Pablo Pires (comunicação pessoal, outubro de 2018), “a Mostra de Tiradentes foi a mais bem-sucedida iniciativa de promoção do cinema nacional em Minas, resultando em uma série de desdobramentos positivos e que fomentam o audiovisual local e nacional". Com ediçóes anuais que duram 
entre 8 e 9 dias, sempre no mês de janeiro ( consecutivas, desde a sua criação em 1998), o festival entrou para o calendário de festivais de cinema nacional e também inaugurou o calendário de eventos hoje existente na cidade de Tiradentes. A mostra, que é voltada para o lançamento de filmes brasileiros, - curtas e longas metragens do circuito comercial, não comercial e universitário - já beneficiou um público estimado em 756 mil pessoas, a partir de uma programação que, além da exibição de filmes, inclui oficinas e debates com diretores e atores, bem como atividades de lazer - lançamentos de livros, shows, performances. Desta forma, possibilita o diálogo entre o cinema e o espectador e, também, entre o cinema e outras manifestações artísticas. Ao mesmo tempo, estima-se que seja responsável pela geração de mais de 2.000 empregos diretos e indiretos [5].

A Mostra de Cinema foi uma iniciativa da Universo Produção, surgida em 1997, a partir de uma demanda da Prefeitura de Tiradentes, que estudava estratégias para impulsionar o turismo. As filmagens de novelas e seriados estavam projetando a cidade no cenário nacional e, neste sentido, o investimento em atrações para o público vinculado ao tema parecia promissor. Ao mesmo tempo, o Centro Cultural Yves Alves[6], que estava em construção na cidade, não tinha ainda uma atribuição definida. A escolha do tema cinema veio, portanto, atender à demanda da prefeitura, mas foi reforçada pela possibilidade de montar uma agenda de exibição de filmes no Centro Cultural ao longo de todo o ano, consolidando o espaço dentro da comunidade de Tiradentes (Hallak, comunicação pessoal, outubro de 2018).

Ao mesmo tempo, na medida em que o projeto foi sendo formatado, identificou-se a efetiva demanda de um festival mineiro, até então inexistente, apesar da importante produção de diretores e produtores do estado. "Diante da lacuna no segmento audiovisual em Minas" (Catálogo da 20 Mostra, 2017), a Universo, então, altera, já para a $1^{\circ}$ edição, o projeto inicial, transformando um evento regional e isolado em uma "mostra anual, consecutiva, permanente", e inscrita na lei Federal de Incentivo à Cultura - Lei Rouanet. O projeto teve a importante contribuição da jornalista Lucia Camargo, cuja experiência na área cultural contribuiu para a construção da sua credibilidade, incluindo os contatos com diretores, atores, produtores e a seleção de filmes nacionais relevantes. "A intenção era fazer um evento audiovisual exibindo somente filmes brasileiros” (Catálogo da 20 Mostra, 2017).

Já na primeira edição, a Mostra homenageou o ator Paulo José e a atriz e cineasta Carla Camurati e exibiu 87 filmes, atingindo um público de 7.500 espectadores (Mostra Tiradentes, c2015). Na programação foram incluídas ainda oficinas e palestras para formação e qualificação, o que permitiu que o evento fosse inscrito como um programa de formação, exibição e difusão no Programa da Secretaria de Cultura para o Fundo de Amparo ao Trabalhador. O patrocínio foi da Telemig, tendo ainda o apoio da Fundação Roberto Marinho que cedeu o Centro Cultural como sede do festival e da Prefeitura, que colaborou principalmente na mobilização junto aos comerciantes locais.

O lançamento da Mostra foi determinante para o desenvolvimento subsequente do turismo na cidade, obtendo boa receptividade por parte da comunidade e também por parte da i mprensa nacional. A $2^{\circ}$ edição consolidou o festival, abrindo, ainda, precedente para a criação de uma série de outros eventos na cidade, (Hallak, comunicação pessoal, outubro de 2018). As estruturas temporárias construídas para abrigar o evento têm procurado traduzir e materializar a imagem da Mostra e seu diálogo com a cidade.

\section{Evolução DA Estrutura do EVEnto AO LONgo DOS ANOS: ORIGENS E DESENVOLVIMENTO}

Ao longo dos anos, a Mostra de Cinema de Tiradentes cresceu em importância no cenário dos festivais culturais e em quantidade de público visitante, evolução que teve que ser acompanhada pelas estruturas necessárias para abrigar o evento. A falta de um espaço permanente para o desenvolvimento das atividades demandou a construção de estruturas temporárias. Com o aumento do público e a consolidação do festival, os 
ambientes evoluíram em termos de dimensões, conforto e segurança (Hallak, comunicação pessoal, setembro de 2018).

A instalação das estruturas temporárias da Mostra de Tiradentes pode ser entendida a partir de quatro fases de desenvolvimento, de acordo com a configuração das instalações. Na primeira delas, baseada na imagem da tenda circense, os espaços ocupados foram o Largo das Mercês e o Centro Yves Alves, além - a partir da $3^{\text {a }}$ edição - do Largo das Forras. Na segunda fase, as tendas passaram a ser instaladas no estacionamento da rodoviária da cidade. $\mathrm{O}$ abandono da lona de circo e a busca de uma referência ligada ao próprio cinema caracterizam a terceira fase. Por fim, a quarta fase propõe uma renovação da linguagem estética, e é marcada pela ampliação do nível de complexidade, a partir do crescimento do público e demandas mais restritivas com relação à segurança, acessibilidade, respeito ao patrimônio, entre outras.

\section{1. $1^{\text {a }}$ fase -1998 a 2000}

Esta fase antecedeu o desenvolvimento turístico que ocorreu após o aparecimento da cidade em novelas e seriados da televisão e a chegada de outros festivais pioneiros, como o de Gastronomia. Inicialmente, em 1998, o espaço destinado pela Secretaria de Cultura para receber o evento e as instalaçóes provisórias foi o Largo das Mercês (fig.1), ocupado principalmente, então, por residências. Não havia, por parte da Prefeitura, nenhuma diretriz a respeito da utilização do espaço que, por se situar em uma baixada, ao longo da margem do ribeirão Santo Antônio, era alagadiço.

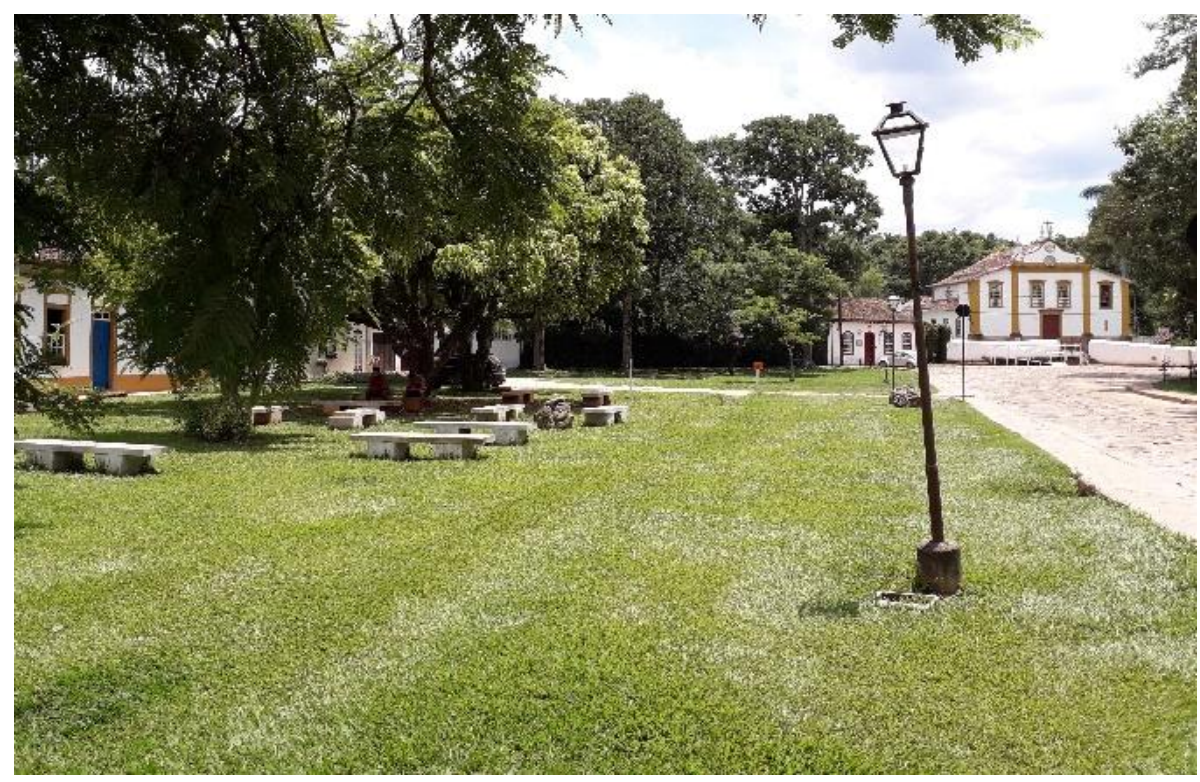

Figura 1. Largo do Mercês.

Fonte: Acervo Universo Produção.

$\mathrm{Na}$ área gramada do largo foram, então, montadas duas lonas de circo, equipadas para abrigar as sessões de cinema, com plateia, área de convivência e hall de entrada. Não houve projeto arquitetônico, sendo a locação e estruturas definidas pela própria produtora. A tenda de circo é funcionalmente inadequada para uma sala de cinema e a adaptação era precária, sem isolamento acústico com piso gramado, que alagava com as chuvas. A área era cercada com gradis de ferro e foi construído um pórtico em andaime para sinalizar a entrada, com a identidade visual do evento, ainda bem simples. Na área externa também eram instalados banheiros químicos para atender ao público. 


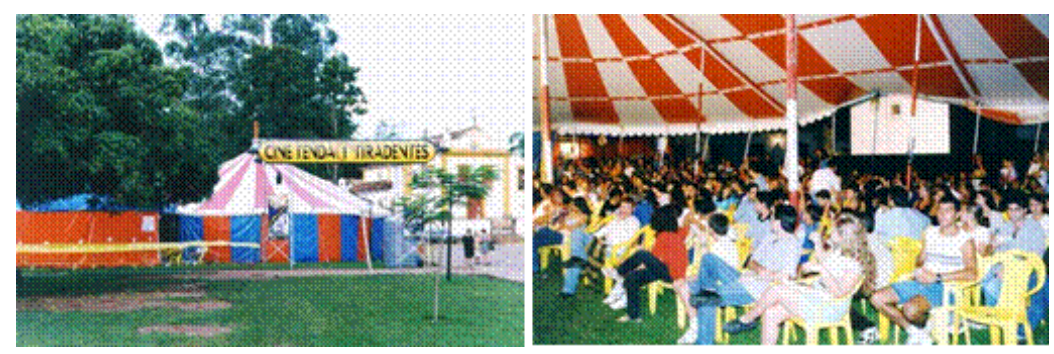

Figura 2. $1^{\text {a }}$ Mostra de Cinema, 1998

Fonte: Acervo Universo Produção.

Segundo Hallak (comunicação pessoal, setembro de 2018), a $1^{\circ}$ edição ocorreu de forma poética, idealizada, e a escolha da tenda circense (fig. 2) se deve mais a uma associação deste tipo de estrutura com o simbolismo do espetáculo itinerante que chega na cidade do interior, do que a qualquer consideração prática. Esta escolha foi importante para a aceitação do novo evento pelos moradores locais, pois fazia referência a uma atividade na qual eles se reconheciam e com a qual se identificavam, criando predisposição para vivenciar uma nova experiência. Pablo Pires (comunicação pessoal, outubro de 2018) destaca os efeitos positivos da gratuidade da programação: "Este aspecto de aproximar o público da cidade, carente de tal informação, lazer e acesso à arte, proporciona um encontro especial e singular entre os festivais brasileiros de cinema. E cumpre um papel social importante."

Além do Largo das Mercês, o Centro Cultural Yves Alves, na rua Direita, também recebeu parte da programação, com exibição de filmes para o público infantil, oficinas, debates, abrigando ainda a secretaria geral do evento. Ele foi inaugurado juntamente com a Mostra, continuando como sede oficial do evento até a edição atual. Por se tratar de um bem tombado, sofreu interferências visuais pequenas, apenas relativas à sinalização.

$\mathrm{Na} 2^{\circ}$ edição, a tenda principal, de forma oval $(18 \times 13 \mathrm{~m})$, passou a ser montada com 2 mastros, para melhorar a visibilidade da tela de projeção (fig.3). A tela era pequena $(8,00 \times 3,50 \mathrm{~m})$, em comparação com o padrão atual, situada entre os mastros, e a capacidade para cada sessão era de 300 espectadores. A segunda tenda, ancorada na principal com um mastro central, atendia à área de convivência, com lounge e bar.
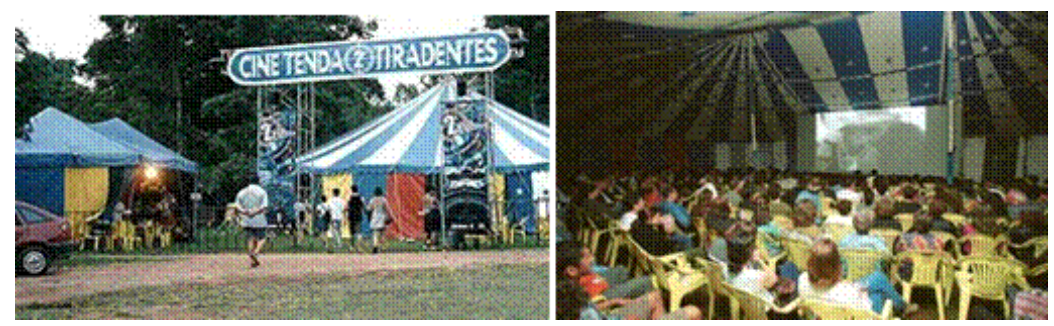

Figura 3. 2a Mostra de Cinema, 1999.

Fonte: Acervo Universo Produção.

Durante toda esta primeira fase, a estrutura temporária continuou sendo montada no Largo da Mercês. Entretanto, com o crescimento do público, isto acabou se mostrando inadequado (Hallak, comunicação pessoal, setembro de 2018). A partir da $3^{a}$ edição do evento (2000), o Largo das Forras também passou a ser ocupado, abrigando o Cine-Praça, espaço para exibição de filmes ao ar livre no período da noite. Durante o evento, foi montada uma estrutura de andaimes e treliças de alumínio para fixação da tela de projeção e uma cabine para o equipamento. Nesta fase, ocupava a lateral leste da praça, com a tela de projeçáo de frente para o prédio da Prefeitura. Todas as noites, os postes da praça eram apagados e as cadeiras para o público eram colocadas a cada sessão, sendo em seguida retiradas, liberando a praça para a circulação e fluxo de pessoas.

Conforme relato de Hallak (comunicação pessoal, setembro de 2018), a inexistência de cinemas, na cidade, e de uma cultura de exibição de filmes ao ar livre no país, fez com que esta novidade constituísse 
um encantamento para os moradores locais. O impacto foi retratado pela rede Globo em seu programa de domingo Fantástico, potencializando a criação do valor simbólico do evento. Sobre a espacialidade, o jornalista Pablo Pires (comunicação pessoal, outubro de 2018), relata a importância da concentração espaçotemporal do festival:

O caráter próprio da cidade pequena e a estrutura do festival, armada em torno de uma área central, faz com que público, jornalistas, produtores, atores e realizadores se encontrem quase que imperativamente. A facilidade de encontro faz com que a interatividade entre todas estas instâncias ocorra de maneira praticamente espontânea, o que é extremamente positivo, tanto para a interação entre os setores produtivos em si (das várias partes do Brasil, trazendo informação e divulgando a produção local para outras regiões, possibilitando contatos e até "supostas" colaborações futuras) e com a imprensa, quanto na relação mais "direta" e "real" do público com o universo da produção cinematográfica. Isso, somado às oficinas realizadas pela organização, são um enorme incentivo para a produção e formação de público do cinema mineiro e nacional.

Nas fases seguintes, o evento passou a ocupar outras áreas, articulando instalações dispostas em vários espaços na região central da cidade.

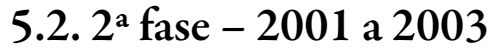

Em 2001, com o crescimento do evento, foi necessário procurar um local mais adequado para montar as estruturas temporárias. Os parâmetros considerados eram: espaço, segurança e facilidade para o fluxo de pessoas, além da necessidade de atender à legislação municipal e ao IPHAN. O local identificado foi o estacionamento da Rodoviária (praça Silva Jardim), que embora nunca tivesse abrigado eventos, estava muito próximo à área central (Largo das Forras) e dispunha de espaço livre para a montagem da estrutura necessária. Outro ponto importante, segundo Vargas (comunicação pessoal, outubro de 2018), era o fato de não estar sujeito às restrições do IPHAN e da legislação municipal.

Apesar da mudança de local, a estrutura ainda funcionava de maneira precária. Nesta fase, eram montadas duas tendas: a primeira delas, uma tenda de circo tradicional, destinada à área de convivência; a segunda, uma tenda galpão, 20,00 x 20,00m, com uma proporção e forma mais adequadas para a exibição de filmes, mas sem acabamentos internos. Nela, funcionava a sala de projeção (fig.4). O valor simbólico da tenda de circo ainda era explorado e ela era montada na frente da tenda galpão (Vargas, comunicação pessoal, setembro de 2018).
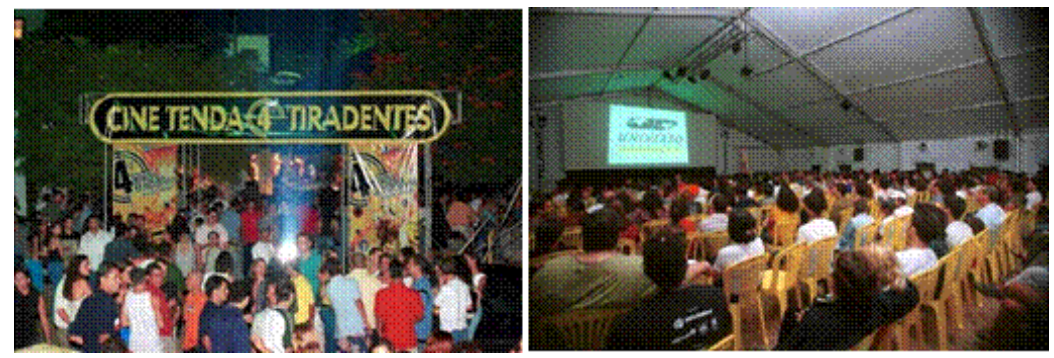

Figura 4. Mostra de cinema, 2001.

Fonte: Acervo Universo Produção.

Não havia ainda tratamento acústico ou térmico e o piso das tendas era o próprio piso do estacionamento, que possuía partes calçadas, mas também canteiros e áreas gramadas, dificultando a acessibilidade. O interior da tenda galpão era todo branco e refletia a luz, o que não favorecia a projeção. Não havia, também, tratamento estético e formal para as estruturas e unidade de conjunto. O pórtico de acesso continuava sendo montado de forma independente, em treliça de alumínio, sendo o principal elemento de sinalização. Esta configuração espacial durou 3 ediçóes.

A abrangência do escopo do evento também passou a demandar novos cuidados: para complementar a programação, que propunha o diálogo do cinema com outras áreas culturais, após as exibições dos filmes, 
eram realizados shows musicais e performances com artistas regionais selecionados pela produção (fig.5), que rapidamente se tornaram um atrativo para a população local e das cidades vizinhas e trouxeram um público crescente a cada ano.
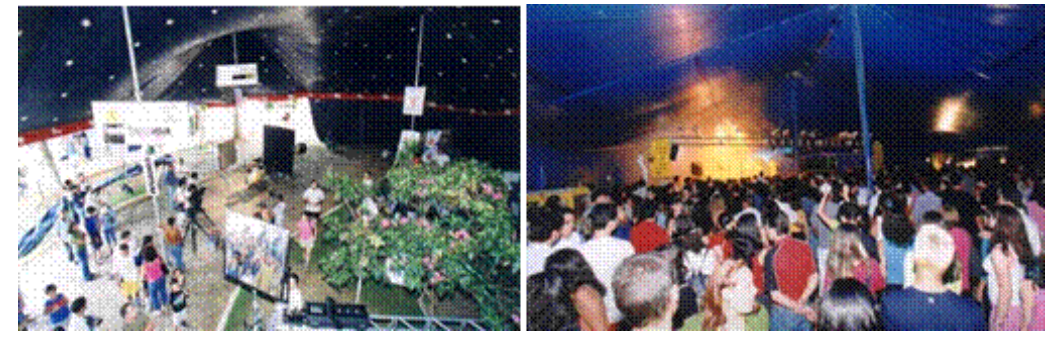

Figura 5. 4a e $5^{\mathrm{a}}$ mostra de cinema 2001/2002.

Fonte: Acervo Universo Produção.

A partir da $5^{\circ}$ edição, uma terceira tenda, também de circo, a Tenda Tecnológica, foi incorporada para abrigar a exibição e demonstração de equipamentos do audiovisual como câmeras, gruas, mesas de edição, dentro do conceito de formação de público especializado (fig.6). Os impactos gerados com o aumento de público repercutiam no fluxo do trânsito ao redor do Largo da Rodoviária, na movimentação de vendedores ambulantes, na capacidade dos espaços construídos, causando preocupação com a segurança dos usuários por parte da produção. Assim, constatou-se a inadequação das tendas e a produção passou a procurar novas alternativas no mercado (Hallak, 2018).
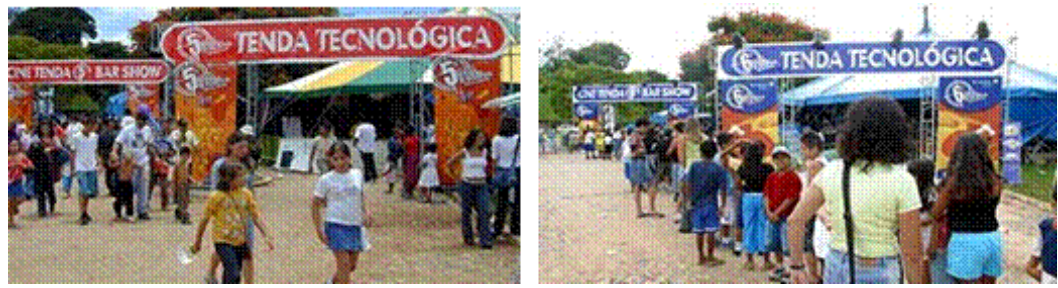

Figura 6. $5^{\mathrm{a}}$ e $6^{\mathrm{a}}$ Mostra de Cinema 2002/2003. Tenda tecnológica incorporada ao projeto Fonte: Site oficial do evento. (Mostra de Cinema, c2015)

\section{3. $3^{\text {a }}$ fase -2004 a 2011}

Nesta etapa, a tenda de circo deu lugar a tendas que simulavam as salas de cinema. Esta referência ocorreu justamente em um momento em que os cinemas desapareciam das grandes cidades, uma manifestação de melancolia em relação ao espaço que as inspirara.

Uma grande tenda galpão com as dimensões de 20,00 x 40,00 m foi montada para receber a sala de exibição e 5 tendas menores foram utilizadas para a instalação da área de shows, bar, café e banheiros químicos (fig.7). A área total de instalação das estruturas provisórias era de $1.200 \mathrm{~m}^{2}$, ocupando agora a maior parte do espaço disponível do estacionamento da Rodoviária, que antes era apenas parcialmente ocupado. Porém, ainda não havia um projeto cenográfico para dar a estas tendas uma unidade formal ou um tratamento estético que expressasse a linguagem visual do evento. A solução para a distribuição dos espaços foi desenvolvida pela própria Universo, com a experiência adquirida ao longo das montagens anteriores, visando melhorar o funcionamento. 


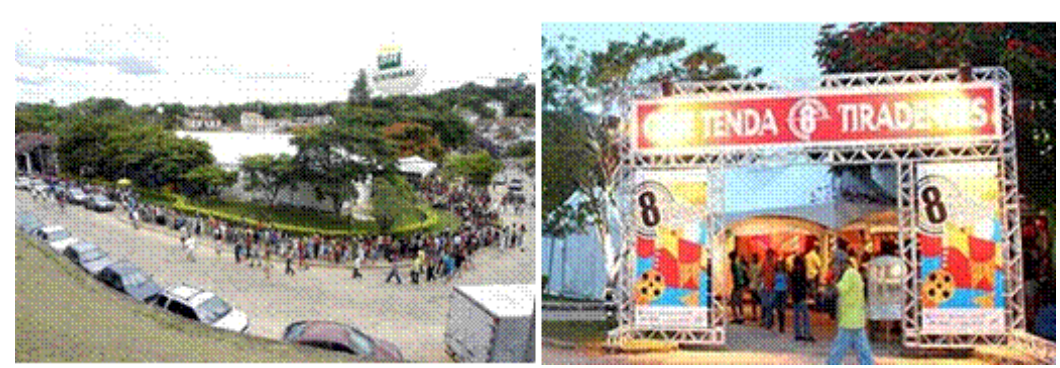

Figura 7. $7^{\mathrm{a}}$ e $8^{\mathrm{a}}$ Mostra de Cinema, 2004/2005. Novas tendas brancas

Fonte: Acervo Universo Produção.

Já na $8^{\circ}$ edição, a distribuição dos espaços no Largo da Rodoviária procurou trazer um melhor aproveitamento da área (fig.8). Para não danificar os gramados existentes foi instalado um piso elevado em todo o interior das tendas, que aumentou o conforto do usuário, permitindo a acessibilidade, e a superação de problemas relativos a alagamentos. Ainda não havia necessidade de aprovação do projeto no IPHAN ou na Prefeitura, porém já existia a demanda de atendimento às exigências do Corpo de Bombeiro quando à segurança contra incêndio e pânico (Vargas, comunicação pessoal, setembro de 2018).



Figura 8. Layout do complexo cine-tenda. "As built" (arquiteta Renata Rocha). Fonte: Acervo Universo Produção.

Em 2006, para a 9a edição, a Universo Produção contratou “[...] uma empresa de arquitetura especializada[7], capaz de acolher as demandas locais [de então], dialogar com o perfil do evento, atender às especificidades técnicas, cumprir as normas do Corpo de Bombeiros". O objetivo também era organizar melhor o funcionamento, a montagem e "criar uma identidade própria e mais definitiva do evento" (Hallak, 2018, p.06).

Assim, houve uma reformulação de toda a estrutura física como resultado de novas experimentações programáticas e inovações formais. Uma das premissas do projeto era o melhor aproveitamento da área do estacionamento (Rocha, comunicação pessoal, outubro de 2018). Neste primeiro projeto, as intervenções formais ainda foram tímidas, mas bastante significativas. Hallak (comunicação pessoal, setembro de 2018) destaca a transição de uma imagem de circo - já abandonada havia 2 edições - para uma imagem 
com referências ao cinema. Neste sentido, foi criado um foyer, com inspiração nos cartazes com luzes, característicos dos cinemas antigos, utilizando a chita, alusão à mineiridade (fig.9). A fachada recebeu uma grande testada em tecido e houve uma evolução na linguagem gráfica, que incorporou os elementos da cenografia. (Rocha, comunicação pessoal, outubro de 2018).
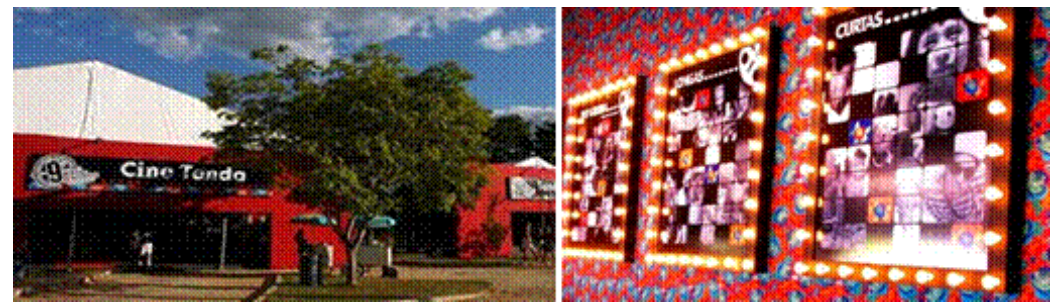

Figura 9. Fachada e interior da 9a Mostra de Cinema, 2006

Fonte: Acervo Universo Produção (foto A) e Site oficial da Dois arquitetura (foto B).

$\mathrm{Na}$ edição seguinte, foi trabalhado o aprimoramento nos fluxos de circulação de entrada e saída da sala de cinema criando para a cabine de projeção um sistema independente das demais estruturas. Desta forma, houve um ganho significativo com relação à qualidade das projeções, que parou de sofrer com as oscilações do piso.

Até então trabalhando de forma autônoma, na $11^{\circ}$ edição, a arquiteta Renata Rocha se associou ao arquiteto José Ricardo e, nas edições seguintes, é possível verificar uma evolução significativa no design interior (fig. 10). Os espaços de convívio, como café, lounge e bar, ganharam um acabamento mais elaborado, aproximando-se de espaços permanentes de cinema, em termos de conforto e funcionalidade. Segundo Rocha (2018), nesta época, surgiu uma demanda maior de espaços exclusivos por parte dos patrocinadores, com uma ambientação mais elaborada, para colocação das marcas.
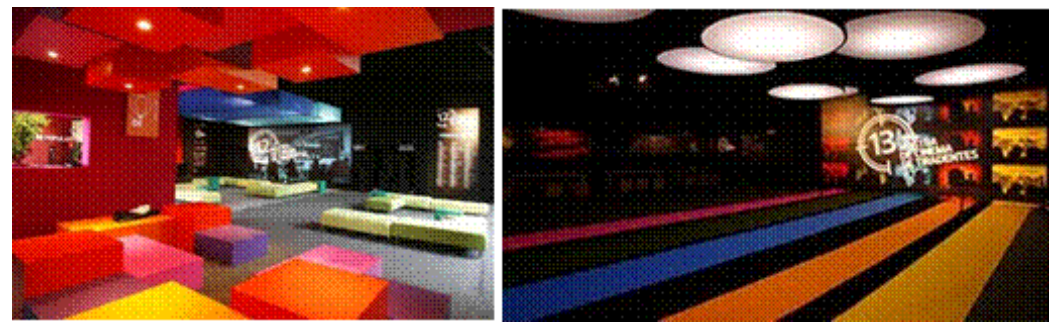

Figura 10. Ambientes internos da $12^{\mathrm{a}}$ e $13^{\mathrm{a}}$ edições.

Fonte: Site oficial da Dois arquitetura. (Dois Arquitetura, 2009) e Acervo Universo Produção (foto B).

Também na $11^{\circ}$ edição, a Universo Produção contratou o designer gráfico Leo Gomes, que passou a ser responsável por toda a identidade do evento, desenvolvendo o tema principal de cada edição. A partir deste momento, criou-se uma unidade de linguagem entre o projeto cenográfico e material de divulgação. Desta forma, o tema aplicado ao mobiliário, luminárias, painéis, bancos, banners, painéis expositivos, era o mesmo do material de divulgação, como cartazes, folders, catálogo e outros (fig.11)..
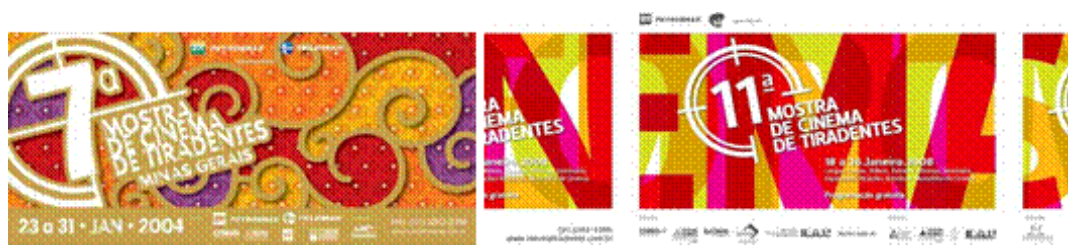

Figura 11. Evolução no material gráfico desenvolvido para a Mostra Fonte: Acervo Universo Produção. 
Com o crescimento da Mostra e a ocupação do centro Histórico e de todo o estacionamento da Rodoviária, que faz parte do perímetro de tombamento do Matadouro Público, tornou-se necessário obter aprovação das instalações junto ao IPHAN, além de controlar a conservação de gramados, árvores e passeios existentes no local. A demanda da Prefeitura, por sua vez, era focada nas medidas mitigatórias em relação ao trânsito, segurança e lixo.

Analisando as fotos e os projetos, observa-se que os ambientes passaram a ser mais confortáveis, com setorização clara e mobiliário específico para cada uso. Identifica-se, ainda, espaços exclusivos para patrocinadores e também painéis criados para conteúdos expositivos - como a linha do tempo sobre a história do cinema brasileiro, ou o destaque fotográfico dado aos atores e diretores homenageados.

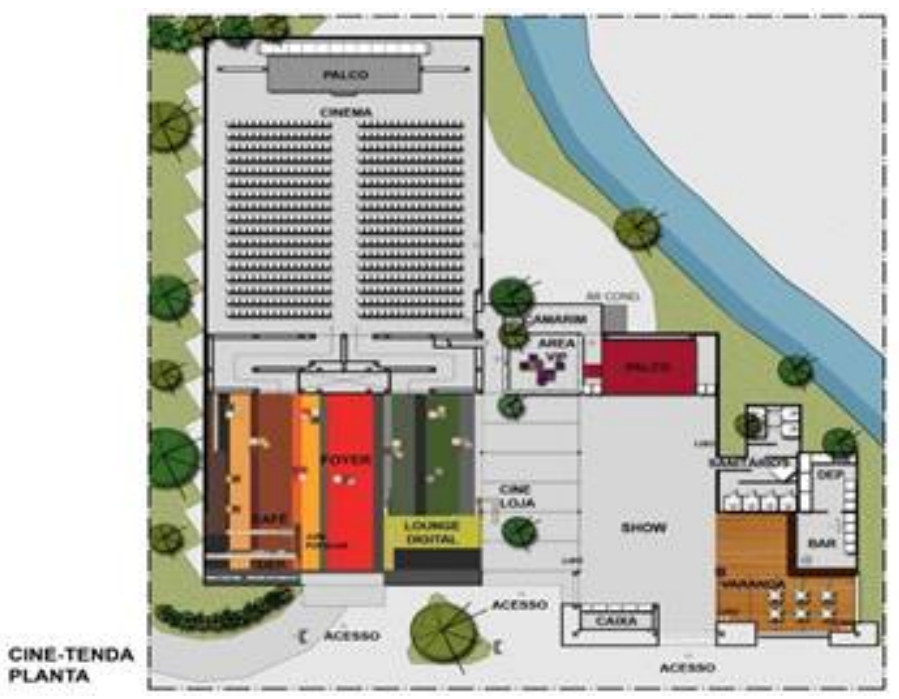

Figura 12. Layout $14^{a}$ Mostra de Cinema (Dois Arquitetura).

Fonte: Acervo Dois Arquitetura (2011).

Houve ainda uma evolução no funcionamento das tendas (fig. 12), que passaram a ter os espaços integrados, com maior conforto e uma preocupação com a circulação do público, atendendo ao fluxo de entrada e saída da sala de cinema. A fachada, por sua vez, ganhou uma volumetria mais destacada, reunindo as tendas e criando uma linguagem mais coerente com a imagem do evento (fig.13).

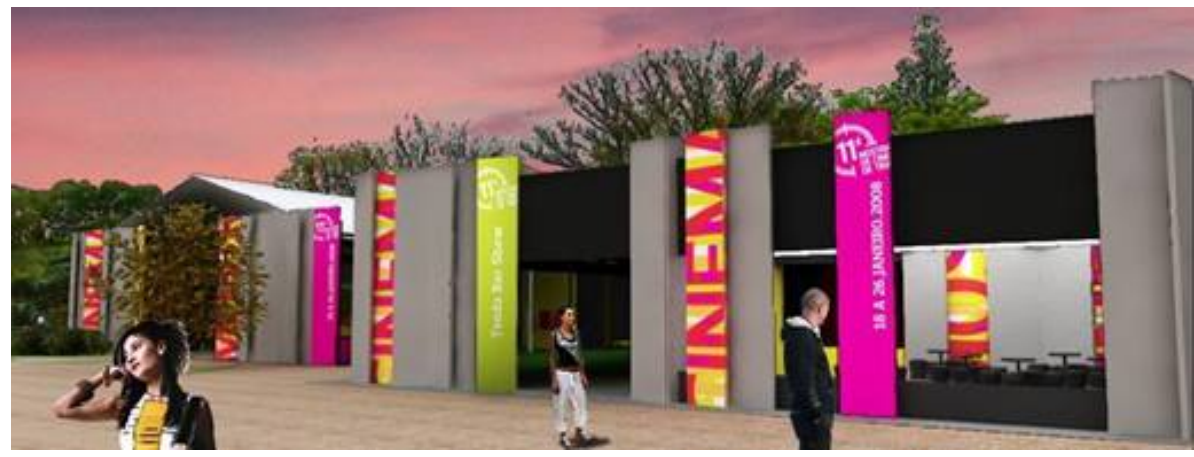

Figura 13. Projeto para a fachada da $11^{\text {a }}$ edição (Dois Arquitetura), 2008 Fonte: Site oficial da Dois Arquitetura (2008).

O largo das Forras também foi contemplado nos projetos. A estrutura para tela de projeção com a cabine do Cine-praça passou a ser montado no sentido norte-sul, com uma capacidade maior de público. O espaço dedicado ao público infantil, com os personagens fictícios criados pela Universo, a Turma da Pipoca (fig.14) foi integrado a partir da identidade visual do evento, recebendo mobiliário colorido, painéis com conteúdo expográfico e brinquedos simples, como amarelinha e jogo da memória. 


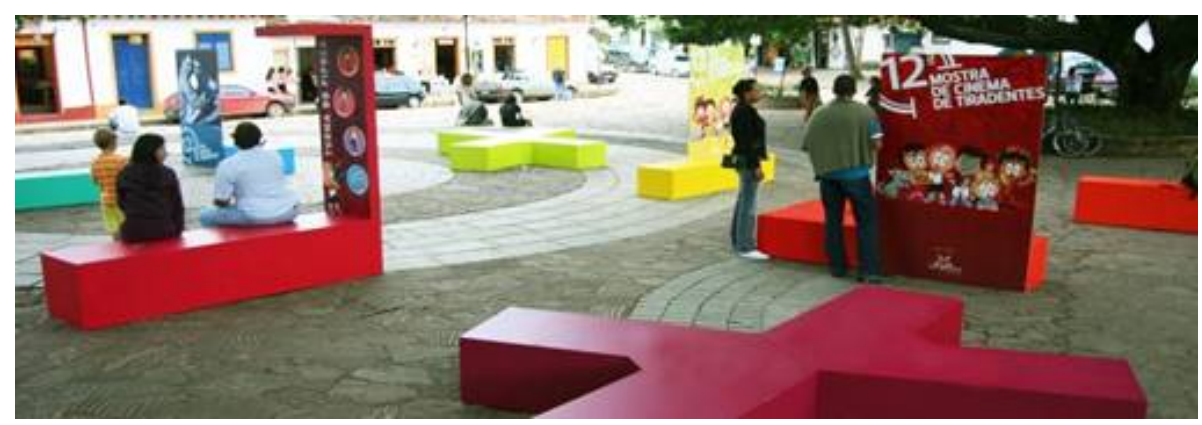

Figura 14. Detalhe do mobiliário $12^{\mathrm{a}}$ edição

Fonte: Site oficial da Dois Arquitetura (2009).

\section{4. $4^{\text {a }}$ fase -2012 a 2018 (atual)}

Em 2011, a produção do evento, visando renovar a linguagem cenográfica e a abordagem, contratou o escritório WN Arquitetura, que já desenvolvia outros trabalhos na área de cenografia. Paulo Waisberg (comunicação pessoal, outubro de 2018), arquiteto sócio do escritório, relata que procurou aproveitar o potencial de comunicação direta do público com o evento, a partir da composição visual das tendas, em sua relação com a escala urbana. Outra estratégia utilizada pelo escritório foi ampliar a paleta de materiais nos acabamentos, trazendo mais texturas e contrastes com os tecidos e lonas usados até então. As fachadas receberam uma placa com a imagem da Mostra (fig. 15) e a produção do evento eliminou também a colocação de banners, blimps (balóes) e faixas com marcas de patrocinadores nas áreas externas e fachada, procurando reduzir o impacto das chamadas comerciais no cenário histórico da cidade.
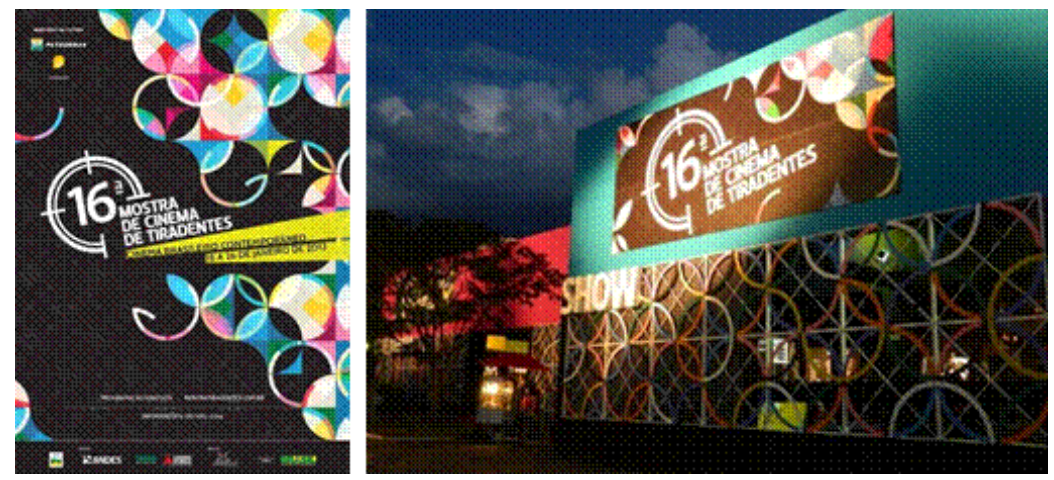

Figura 15. Fachada do Cine-tenda na 16a edição realizada em 2013.

Fonte: Acervo Universo Produção (foto A) e acervo WN Arquitetura (foto B).

Nesta fase, o projeto continuou evoluindo, com novas transformações no funcionamento dos espaços internos e na estratégia de composição buscando uma integração ainda maior das tendas. A quantidade delas foi reduzida para três, utilizando duas coberturas montadas "in loco", para conexão entre o recorte para as árvores existentes e a varanda. Novas configurações para o lounge, café, bar, banheiros foram desenvolvidas, sempre visando atender o funcionamento, face ao aumento de público. A partir do crescente sucesso dos shows, na $15^{\circ}$ edição, o palco teve suas dimensões ampliadas e foi elevado, para melhorar a visibilidade; a área do bar também foi aumentada. O complexo de tendas passou a ocupar $1.500 \mathrm{~m}^{2}$.

Esta configuração foi mantida até a $17^{\circ}$ edição. Entretanto, o aumento do público atraído pelos shows começou a causar transtornos na cidade, além de tirar o foco do tema principal do evento, o cinema. Assim, o conceito dos shows foi reformulado na $18^{\circ}$ edição, buscando um viés mais cultural por meio de "pocket 
shows", integrando música e vídeos, compatibilizando conteúdos. O projeto do palco foi, em decorrência, alterado, tendo suas dimensões reduzidas e passando a ser elevado em apenas $30 \mathrm{~cm}$ (fig. 16).
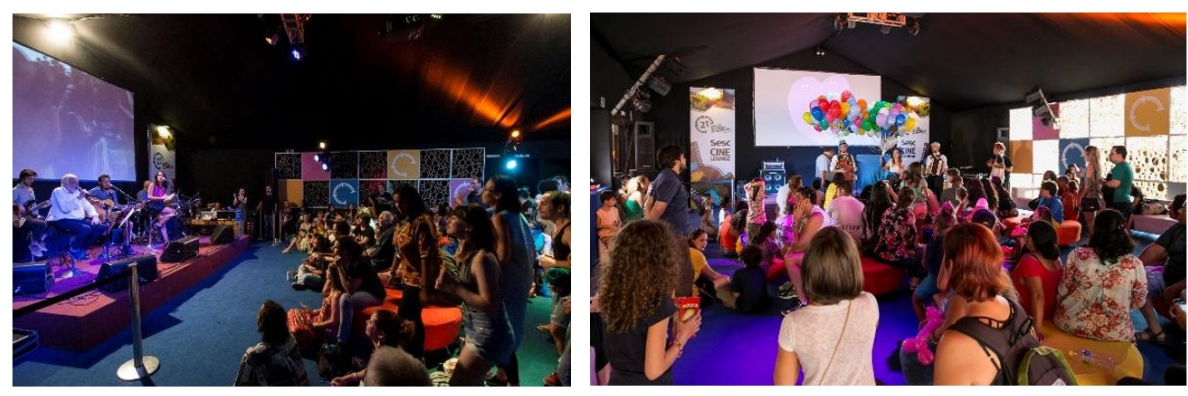

Figura 16. Palco da Tenda-show na $21^{a}$ edição.

Fonte: Acervo da Universo Produção.

Outra alteração importante, segundo Waisberg (comunicação pessoal, outubro de 2018), foi o aumento da permeabilidade e ventilação das tendas (fig. 17). Como o evento acontece no verão, são instalados aparelhos de ar-condicionado na sala de exibição. Nas áreas de convivência, como café e palco, que não recebem ventilação artificial, a solução foi a substituição dos painéis de fechamentos por painéis vazados, o que, além de melhorar o conforto térmico permitiu também uma integração maior com as áreas externas: uma permeabilidade visual que valorizou o contexto histórico de inserção.
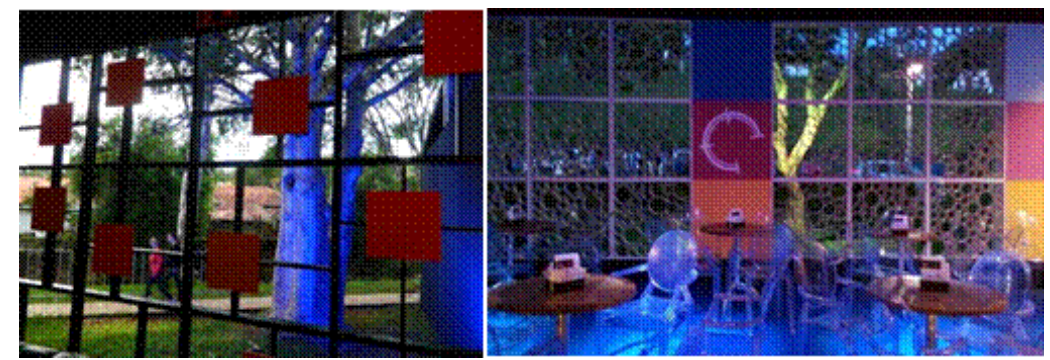

Figura 17. Detalhe dos painéis vazados da $19^{\mathrm{a}}$ e $21^{\mathrm{a}}$ edições Fonte: Acervo WN Arquitetura.

Os projetos procuram explorar os materiais e formas inusitadas na cenografia dos ambientes internos e fachada para renovação da imagem a cada edição (fig. 18). Segundo Waisberg (comunicação pessoal, outubro de 2018), os elementos cenográficos são importantes para a divulgação do evento, pois estimulam a difusão nas redes sociais, ampliando o alcance das mídias tradicionais. 


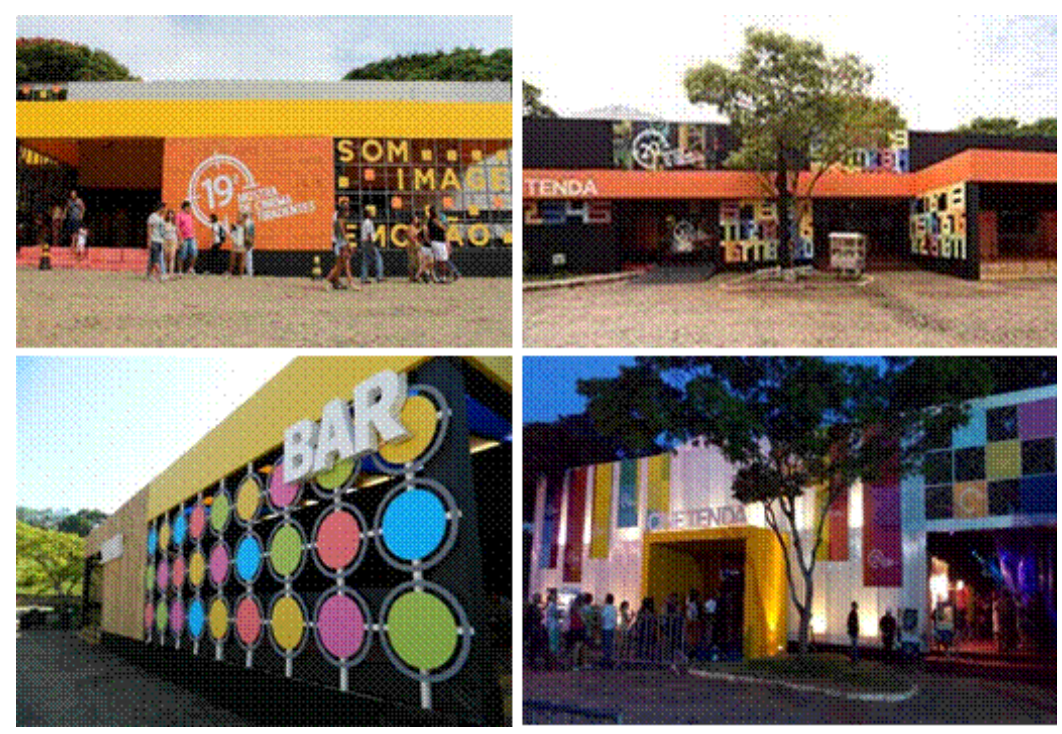

Figura 18. Detalhes das fachadas da $16^{\circ}, 19^{\circ}, 20^{\circ}$ e $21^{\circ}$ edições.

Fonte: Acervo WN arquitetura.

A relação com os patrocinadores também tem sido um desafio, uma vez que cabe ao projeto cenográfico ambientar e potencializar as marcas sem descaracterizar a imagem geral do evento (fig.19).
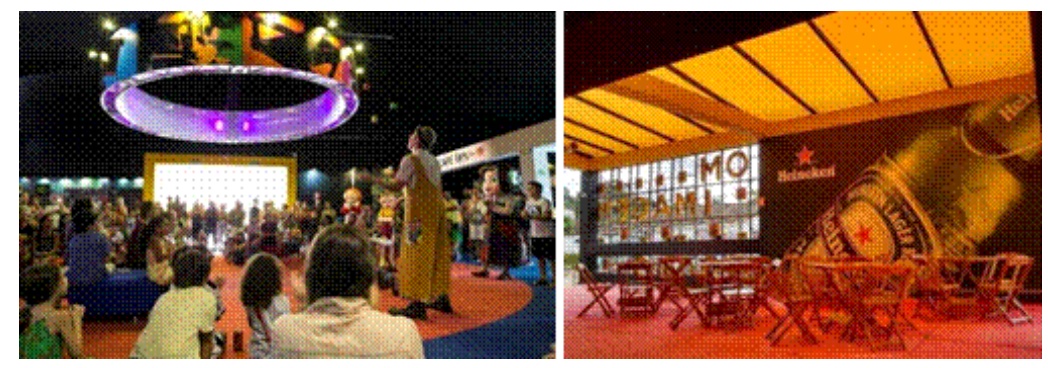

Figura 19. Áreas de convivência no interior das tendas.

Fonte: Acervo Universo Produção (foto A) e acervo WN Arquitetura (foto B).

O Largo das Forras também tem sido explorado na fase atual da Mostra. A disposição anterior para a tela foi mantida, agregando uma área expositiva em estrutura de alumínio curvo, acompanhando o desenho da praça, na qual são expostos painéis fotográficos que procuram dialogar com a cidade e com a sua história. (fig.20). A turma do Pipoca, bonecos que retratam os personagens do cinema, colore o espaço público resgatando brincadeiras antigas. A praça se coloca como lugar de encontro, descanso e diversão, mantendo uma relação com sua função urbana.
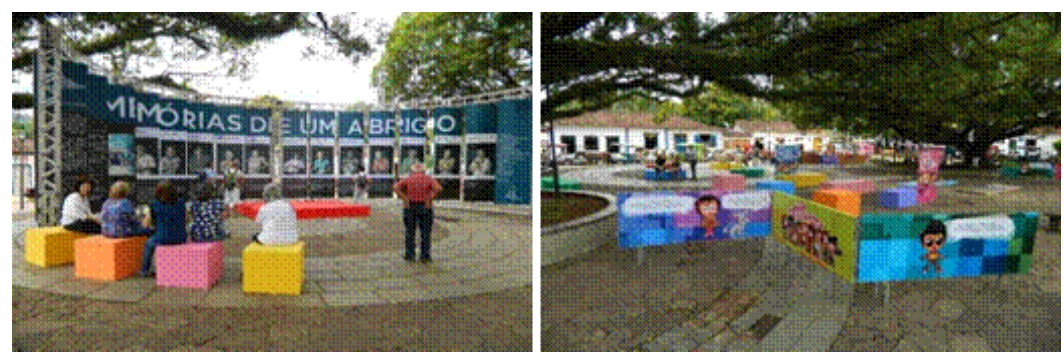

Figura 20. Exposição e área da turma do Pipoca. (Largo das Forras). Fonte: Acervo WN Arquitetura (foto A) e Acervo Universo Produção (foto B). 
Com relação à regulamentação, atualmente os projetos e descritivos, elaborados pelos arquitetos devem ser protocolados no IPHAN que, muitas vezes, firma termos de ajuste de conduta com a produção do evento, para a superação de situações que possam ser consideradas como risco para o patrimônio local. O IPHAN também exige que o evento atenda à legislação de Uso e Ocupação do Solo, respeitando a altimetria de 6,00 metros (cota média do conjunto). Uma exceção é feita com relação à cumeeira da tenda principal que ultrapassa essa marca, levando-se em conta as especificidades do evento, e a necessidade de abrigar a tela de projeção. Segundo o relatório da Universo (Hallak, 2018), a cada ano o projeto cenográfico se adequa às orientações definidas a partir das negociações em reuniões promovidas pelo Ministério Público Federal com a participação da Prefeitura Municipal, da Câmara Municipal, do IPHAN - Tiradentes - da Polícia Militar, do Corpo de Bombeiros e das Associações Comunitárias e Empresariais.

Com um público estimado em quarenta mil pessoas (Mostra Tiradentes, c2015), as exigências do Corpo de Bombeiro aumentaram. Novas soluções de saída de emergência passaram a ser exigidas (fig.21) e os materiais de acabamento passaram a receber tratamento ignifugante (retardante de chamas).

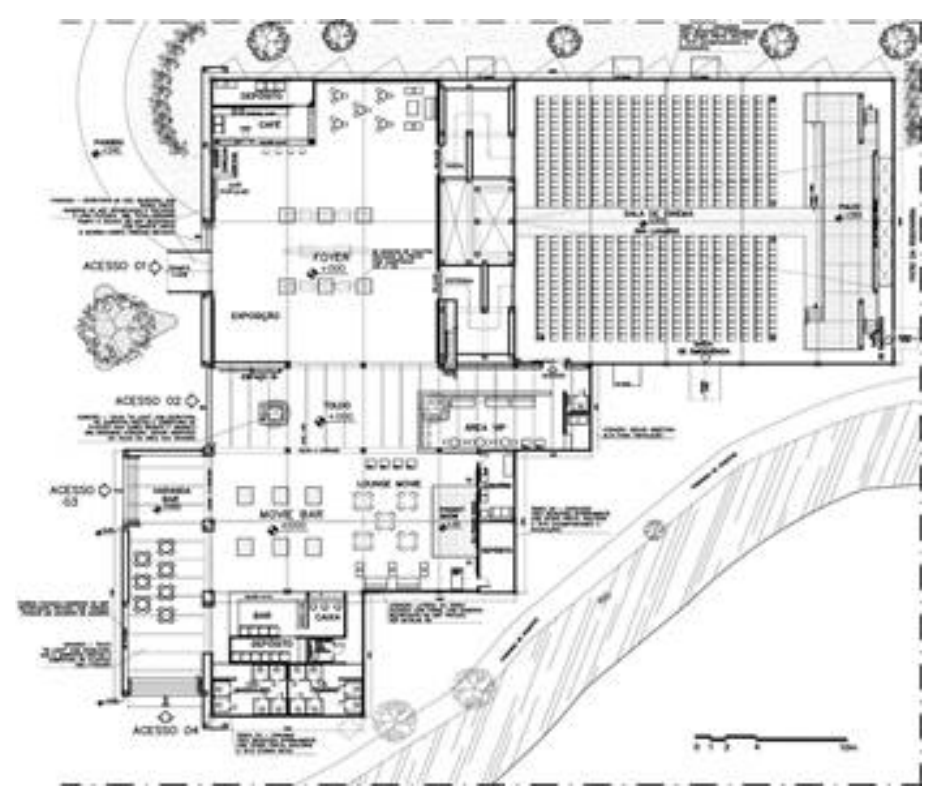

Figura 21. Planta Layout da Cine-tenda na 20a edição.

Fonte: Acervo WN arquitetura (WN Arquitetura, 2017).

Do ponto de vista da acessibilidade, o piso interno foi todo nivelado, e todas as rampas e escadas de acesso foram equipadas com guarda-corpo. Já a qualidade técnica das exibições dos filmes, tanto na tenda como na praça (fig.22) garante a participação apropriada de diretores e produtores.
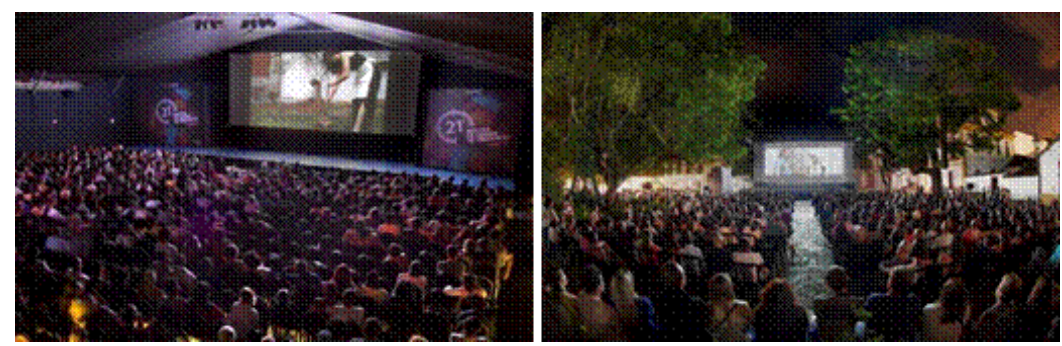

Figura 22. Cine Tenda e Cine Praça.

Fonte: Acervo Universo Produção.

O público, por sua vez, com muitos reincidentes, encontra, nos espaços construídos, conforto e segurança para dedicar horas à imersão no universo audiovisual. Ao mesmo tempo, o ambiente que "o caráter próprio da 
cidade pequena e a estrutura do Festival” propicia, impõe encontros inesperados, interatividade espontânea, aprendizado, experiências... constrói memórias.

\section{Considerações Finais}

Existem diversas perspectivas de análise sobre a apropriação que o turismo cultural faz do patrimônio em tempos globalizados. Uma delas, que tem sido bastante discutida, é a questão das desigualdades, que são em geral reforçadas neste processo: "O turismo, por si só, não é capaz de reverter as realidades históricas das desigualdades socioregionais" (Costa, 2010, p. 5). De fato, conforme destaca Bauman (1999), a nova realidade do espaço globalizado, que promove a hibridização cultural dos habitantes "pode ser uma experiência criativa e emancipadora, mas a perda de poder cultural dos habitantes locais raramente o é" (p. 109).

Os dados econômicos demonstram que o turismo tem feito a cidade de Tiradentes avançar do ponto de vista econômico, melhorando seus índices de desenvolvimento humano[8], possibilitando a permanência de moradores, antes obrigados a migrar à procura de emprego (Neves \& Carneiro, 2014). Por outro lado, devido à falta de qualificação da população local, os empregos em geral são informais e de baixa remuneração. As desigualdades prevalecem e os habitantes locais se deslocam para as periferias, a partir de um processo de gentrificação.

Porém, a discussão que este artigo procurou trazer está focada em outro aspecto, também controverso: as relações entre o patrimônio construído e as novas formas de expressão cultural e sua interação para a configuração da identidade local. A nova realidade do mundo globalizado, com suas formas de expressão, "pode ser repressiva e alienante, se impedir a reflexão e o critério, mas também pode ser integrante e libertadora, se apresentar-se como um processo de estruturação da cultura” (Argan, 2005, p. 264).

A transformação a que se assiste hoje nas cidades ocorre a partir da aproximação entre o cotidiano, o consumo e o espetáculo, e de uma indefinição dos contornos que separam a compra, o aprendizado e a experiência da cultura. Em eventos e festivais, este fenômeno é evidente, pois permite aos indivíduos "inventar - por meio da memória, imaginação e desejo, novas ideias sobre si mesmos e suas relações com a paisagem urbana” (Makeham, 2005, p. 157). A arquitetura efêmera consegue acompanhar o ritmo destas experiências e reconstruir significados, articulando as diferentes perspectivas que compóem a realidade mutante e fragmentada.

Em Tiradentes, as instalações montadas para a Mostra de Cinema têm feito a mediação entre os habitantes e os visitantes, entre o espaço local e o mundo contemporâneo, entre o cinema, o conhecimento e o consumo.

Estas relações estão inseridas no contexto do turismo cultural, que é "vivência do conjunto de elementos significativos do patrimônio histórico e cultural e dos eventos culturais, valorizando e promovendo os bens materiais e imateriais da cultura" (Ministério do Turismo, 2008). A cada ano, as instalações evoluem para se moldar às demandas emergentes no ambiente e na cultura. Deste ponto de vista, a cidade, enquanto experiência cotidiana, tem se tornado "um texto negociável e passível de ser projetado" - no qual se confundem espaço vivido e espaço projetado - "em vez de um sistema dominante de estruturas de poder" (Makeham, 2005, p. 157). A cada ano, o projeto e a cenografia têm sido aprimorados e readequados para receber um público cada vez maior, com mais demandas, dentro de um contexto de diálogo com a tradição, de sedução da imagem, de encanto.

Durante a Mostra de Cinema, portanto, as estruturas temporárias têm ressignificado os espaços urbanos nos quais atuam de uma forma dinâmica, acompanhando o ritmo da cidade. Existe uma adequação às exigências da legislação e da população local, mas também ao ritmo do mundo, trazendo pessoas e ideias de fora e novas perspectivas para uma cidade que não se resume a seu passado, materializando a dialética global/ local que deve perpassar qualquer identidade contemporânea: uma identidade fragmentada e por isso mesmo, rearticulável, moldável, polivalente. 
Embora de curta duração, o legado do evento, material e imaterial, tem longa duração conforme preconiza Steffani (2011) sua recorrência faz com que não seja episódio isolado, tendo, portanto, impacto nas políticas públicas locais, definindo novas possibilidades de desenvolvimento urbano, no qual se inserem novos atores.

Desta forma, questões como a própria efemeridade, a excepcionalidade e a ocasionalidade foram relativizadas, a partir da incorporação da Mostra nas práticas urbanas locais. A arquitetura efêmera conseguiu, assim, estabelecer o evento na cidade de forma permanente - embora sempre provisória. A Mostra por sua vez, abriu espaço para uma nova agenda de eventos, que trouxe a articulação com a contemporaneidade para o processo de construção identitária local, até então organizado em torno da história, com foco no passado. Criatividade e cultura foram centrais neste processo.

Por fim, resta destacar que o próprio tema da Mostra, o cinema, é uma arte em sintonia com estas dinâmicas fluidas e mutáveis, exercitando o homem, conforme coloca Benjamim (1996), nas novas percepções e reações demandadas pelo nosso tempo, "uma tarefa histórica cuja realização dá ao cinema o seu verdadeiro sentido" (p. 174). A cultura se afirma, desta forma, enquanto "ciência interpretativa, à procura de significados" (Geertz,1973, p.15).

\section{REFERÊNCIAS}

Abreu, M. A. (2017). Sobre a memória das cidades. In: CARLOS et al. (Org.), A produção do espaço urbano. (p.19-40). São Paulo: Contexto.

Argan. G. C. (2005). História da arte como história da cidade. São Paulo: Martins Fontes.

Bauman, Z. (1999). Globalização: As conseqüências humanas. Rio de Janeiro: Jorge Zahar.

Bauman, Z. (2001). Modernidade líquida. Rio de Janeiro: Jorge Zahar.

Bauman, Z. (2005). Identidade: Entrevista a Benedetto Vecchi. Rio de Janeiro: Jorge Zahar.

Benjamin, W. (1996). Magia e técnica, arte e política. São Paulo: Brasiliense.

Brasil (2018). Ministério do Turismo. Plano Nacional de Turismo 2018-2022: mais emprego e renda para o Brasil. Recuperado de http://www.turismo.gov.br/images/mtur-pnt-web2.pdf.

Canclini, N. G. (1999). Consumidores e cidadãos: Conflitos multi-culturais da globalização. Rio de Janeiro: UFRJ.

Canclini, N. G. (1997). Culturas Hibridas: Estratégias para entrar e sair da modernidade. São Paulo: EDUSP.

Castro, M. L., Ximenes, T. (2006, jul./dez). Design e inovação na Amazônia Brasileira. Amazônia: Ciência \& desenvolvimento. 2 (3) p.39-55. Belém: Banco da Amazônia.

Costa, E. B. da, Castro, B. (2008). O processo de "banalização pela cenarização" em núcleos urbanos tombados: o caso de Tiradentes-MG. Revista Geografias 4 (1) p. 23-40. Recuperado de https://www.yumpu.com/pt/document/ $\mathrm{read} / 26815056 /$ janeiro-junho-vol-4-na-1-2008-issn-1808-8058-igc-ufmg

Dois Arquitetura e Design (2006). Homepage com a apresentação da $10^{a}$ Mostra De Cinema De Tiradentes 2007. Disponível em: <http://dois.arq.br/portfolio/mostra-de-cinema-de-tiradentes-2006/>; Acesso em: 05 out 2018.

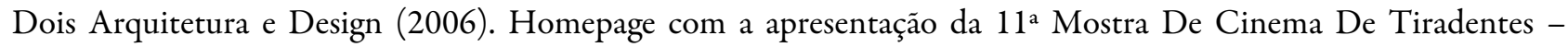
2007. Disponível em: <http://dois.arq.br/portfolio/mostra-de-cinema-de-tiradentes-2007/>; Acesso em: 05 out 2018.

Dorfles, G. (1991). O design industrial e a sua estética. Lisboa: Editorial Presença Ltda.

FIEMG. Desenvolvido por Webmaster do Sistema FIEMG. (2013). Apresenta informações sobre o Centro Cultural SESIMINAS Tiradentes. Disponível em: <https://www7.fiemg.com.br/sesi/centro-de-cultura/tiradentes/sob re>; Acesso em: 01 Set. 2018.

Greertz, C. (1973). A interpretação das culturas. Rio de Janeiro: Jorge Zahar.

Geertz, C. (2001). Nova luz sobre a antropologia. Rio de Janeiro: Jorge Zahar.

Halls, S. (2006). A identidade cultural na pós modernidade. Rio de Janeiro: DP\&A. 
Hallak, R. (2018). "Resposta ao Termo de Compromisso - 21" Mostra de Cinema de Tiradentes". Documento enviado ao IPHAN em 05 de janeiro de 2018.

Harvey, D. (1992). A Condição pós-moderna. São paulo: Edições Loyola.

Kronenburg, R. (2010). Live architecture: The design of portable buildings for live music performance. Architectural Research Quarterly, 14(4) p.304-316. doi:10.1017/S1359135511000108

Madureira, M. A. (2011). A construção do Largo das Forras como patrimônio. 156 fls. Dissertação (Dissertação de Mestrado Arquitetura). Faculdade de Arquitetura e Urbanismo-USP, São Paulo, SP.

Makeham, P. (2005). Performing the City. Theatre Research International, 30(2) p.150-160. doi:10.1017/ S030788330500115X

Mostra Tiradentes (2015). Desenvolvido por Universo Produção, c2015. Homepage com informações sobre a Mostra de Cinema de Tiradentes. Disponível em: <http://mostratiradentes.com.br/inicio $>$; Acesso em: ago a nov 2018.

Neves, R.., Carneiro, E. J. (2014). Empreendedorismo e marketing urbano: a mercadorização do centro "histórico" de Tiradentes, Minas Gerais, na ótica do turismo. Revista Cenário. 2 (2) p. 65-81. Recuperado de https://periodic os.unb.br/index.php/revistacenario/article/view/15193/13504.

Pellegrini, A., Fo. (2000). Turismo Cultural de Tiradentes. São Paulo: Manole Ltda.

Santos, M. (2000). Por uma outra globalização: do pensamento único à consciência universal. Rio de Janeiro: Record.

Steffani, A. (2011). A la carte urban policies. Mega-events: from exceptionality to construction of ordinary planning practices. Science - Future of Lithuania. . (3), p. 23. Retrieved from http://link-galegroup.ez27.periodicos.capes. gov.br/apps/doc/A266942741/AONE?u=capes\&sid=AONE\&xid=012675f7.

Universo Produção (Orgs.). (2017). 20 Mostra de cinema de Tiradentes. Catálogo geral. Belo Horizonte: Universo Produção.

WN Arquitetura (2014). Homepage com a apresentação da empresa e seu portfólio de eventos. Disponível em: http s://wnarquitetura.com/. Acesso em: ago 2018

\section{Notas}

[1] Embora, muitas vezes, criando artifícios para adequar este patrimônio a um sistema de expectativas ligado ao mercado turístico - como, por exemplo, a construção de edificações contemporâneas como pastiche das antigas, "um falso histórico" (Madureira, 2011).

[2] O Plano de Turismo 2018-2022 elaborado pelo Ministério do Turismo estabelece diretrizes visando estruturar centros para funcionarem como âncora para desenvolvimento regional e Tiradentes é um desses centros. (BRASIL, 2018, p.55).

[3] Referência a CANCLINI (1999). p.145: "[...] esses referentes de identificação, historicamente mutáveis, foram embalsamados pelo folclore em um estágio 'tradicional' de seu desenvolvimento, e foram declarados essência da cultura nacional" (p.145)

[4] A minissérie "Memorial de Maria Moura" (1994), cujo enredo original se passa no nordeste brasileiro e o longa metragem "Menino Maluquinho" (1995) foram as primeiras filmagens realizadas na cidade. Na sequência a cidade seria o palco para diversas outras obras: a minissérie "Hilda Furacão" (1998), da rede Globo, cujo enredo original se passa na Belo Horizonte dos anos 1950 (fig.6). "Coração de Estudante" (2002), uma novela cuja trama se desenvolve na cidade fictícia de Nova Aliança, "Essas Mulheres" (2005) novela da TV Record e "Chico Xavier, O filme" (2010), dentre outros. Destaca-se desta forma que Tiradentes não se tornou palco para encenações dos séculos XVIII e XIX ou a representação de uma tipologia específica mas, sim, um cenário em contraponto à urbanização acelerada do século XX.

[5] http://prodview.com.br/2019/01/27/balanco-22a-mostra-tiradentes-programacao-intensa-atrai-mais-de-750-milpessoas-e-goias-se-destaca-na-premiacao/

[6] O Centro Cultural foi idealizado por Yves Alves através da SAT - Sociedade dos amigos de Tiradentes, com o apoio da Prefeitura, proprietária do terreno da sede, e com o patrocínio da Fundação Roberto Marinho através da Lei federal de Incentivo a Cultura e da Rede Globo Minas. A inauguração ocorreu em janeiro de 1998 e em 2009 passou a ser administrado pelo Sesi/Fiemg (FIEMG, c2013)

[7] Escritório de arquitetura Dois Arquitetura e Design, tendo à frente a arquiteta Renata Rocha.

[8] O avanço nos índices de desenvolvimento humano local é notório (antes da implantação da agenda de eventos, em 1991 era de 0,465 - abaixo da média de Minas Gerais 0,493; e em 2010, passou a 0,740 acima da média do estado - 0,727. A 
proporção de pessoas com renda domiciliar per capita inferior a $\mathrm{R} \$ 140,00$ diminuiu de 47,89\%, em 1991, para 7,07\%, em 2010. ( ATLAS, 2013) 